\title{
Analyzing The Effect of BI 7-Days Repo Rate on The Jakarta Composite Index Using Nonparametric Regression Approaches Based on Least Square Spline Estimator
}

\author{
Analisis Pengaruh BI 7-Days Repo Rate Terhadap Indeks Harga Saham \\ Gabungan Menggunakan Pendekatan Regresi Nonparametrik \\ Berdasarkan Estimator Least Square Spline
}

\author{
Christopher Andreas $^{1)}$, Feevrinna Yohannes $\mathbf{H}^{2)}$, Elfhira Juli $\mathrm{S}^{3)}$, Nur Chamidah ${ }^{4 *}$
}

\begin{abstract}
During the Covid-19 pandemic, the Indonesia stock market was under great pressure, so that the value of the Jakarta Composite Index (JCI) fluctuated greatly. To maintain economic stability, Bank Indonesia has regulated monetary policy such as setting the BI 7-Days Repo Rate. Analysis of this effect is important to formulate the right policy. This study aims to design the best model in describing the relationship between JCI value and BI 7-Days Repo Rate. The analysis was carried out by using parametric regression approach based on the ordinary least square method and nonparametric regression approach based on least square spline estimator. The results showed that the parametric regression models failed to meet the classical assumptions. Meanwhile, nonparametric regression can produce an optimal model with high accurate prediction, with an overall mean absolute percentage error value of $3.16 \%$. Furthermore, mean square error, coefficient of determination, and mean absolute deviation also show good results. Thus, the effect of the BI 7-Days Repo Rate on the JCI value forms a quadratic pattern, in which a positive relationship is formed when the BI 7-Days Repo Rate is set at more than $4.25 \%$ and vice versa for a negative relationship.
\end{abstract}

Keywords: BI 7-Days Repo Rate, Jakarta Composite Index, Least Square Spline, Nonparametric Regression, Parametric Regression.

\begin{abstract}
Abstrak
Selama pandemi Covid-19, pasar saham Indonesia mengalami berbagai tekanan besar yang

1,2,3,4 Mahasiswa Departemen Matematika, Universitas Airlangga,

Email : christopher.andreas-2018@fst.unair.ac.id ${ }^{l}$,feevrinayh@gmail.com², elfhirajulisafitrii@gmail.com ${ }^{3}$.Correspondingauthor:nur-c@fst.unair.ac.id ${ }^{4}$

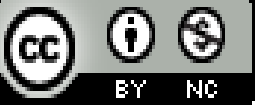
menyebabkan nilai Indeks Harga Saham Gabungan (IHSG) sangat berfluktuasi. Untuk menjaga stabilitas ekonomi, Bank Indonesia menerapkan kebijakan moneter seperti penetapan BI 7-Days Repo Rate. Analisis pengaruh dari BI 7-Days Repo Rate terhadap IHSG sangat penting guna merumuskan kebijakan yang tepat. Penelitian ini bertujuan untuk membentuk model terbaik dalam mendeskripsikan hubungan antara nilai IHSG dan BI 7-Days Repo Rate. Analisis dilakukan dengan pendekatan regresi parametrik menggunakan metode ordinay least square dan pendekatan regresi nonparametrik menggunakan estimator least square spline. Hasil penelitian menunjukkan bahwa

This work is licensed under a Creative Commons Attribution-NonCommercial 4.0 International License 


\title{
Jurnal Matematika, Statistika \& Komputasi Christopher Andreas, Feevrinna Yohannes H, Elfhira Juli S, Nur Chamidah
}

\begin{abstract}
model regresi parametrik gagal memenuhi asumsi klasik. Sedangkan, regresi nonparametrik berhasil mendapat model yang optimal dengan akurasi yang sangat tinggi, dengan nilai mean absolute percentage error keseluruhan sebesar 3.16\%. Lebih lanjut, nilai mean square error, koefisien determinasi, dan mean absolute deviation juga menunjukkan hasil yang baik. Dengan demikian, pengaruh BI 7-Days Repo Rate dan nilai IHSG membentuk pola kuadratik dengan hubungan positif terjadi ketika BI 7-Days Repo Rate berada pada tingkat lebih dari $4.25 \%$ dan sebaliknya untuk hubungan negatif.
\end{abstract}

Kata kunci: BI 7-Days Repo Rate, Indeks Harga Saham Gabungan, Least Square Spline, Regresi Nonparametrik, Regresi Parametrik.

\section{PENDAHULUAN}

Dalam waktu singkat, pandemi Covid-19 menciptakan perubahan dalam tatanan kehidupan masyarakat di berbagai negara, termasuk di Indonesia. Demi memutus rantai penyebaran Covid19 , pemerintah telah menerapkan berbagai langkah strategis diantaranya menelusuri kontak dari pasien yang sudah terinfeksi, melakukan berbagai tes cepat secara masif di berbagai daerah di Indonesia, hingga memberlakukan kebijakan pembatasan sosial berskala besar. Selain itu, pemerintah juga telah melakukan berbagai sosialisasi untuk melaksanakan protokol kesehatan selama beraktivitas [3]. Kondisi tersebut membawa dampak signifikan bagi seluruh sektor kehidupan seperti sektor ekonomi.

Berdasarkan data Badan Pusat Statistik (BPS), Indonesia mencatatkan pertumbuhan ekonomi sebesar $-3,49 \%$ pada kuartal III tahun 2020 jika dibandingkan pada periode yang sama tahun lalu. Hal ini membuat Indonesia resmi mengalami resesi ekonomi. Kondisi tersebut membuat pasar modal Indonesia mengalami berbagai tekanan [8]. Indeks Harga Saham Gabungan (IHSG) bergerak dengan sangat fluktuatif dan pernah mencapai level terendah pada 24 Maret 2020 di angka 3.937. Kondisi tersebut membuat pemerintah melalui Otoritas Jasa Keuangan (OJK) mengeluarkan berbagai kebijakan seperti memberlakukan trading halt dan perubahan terhadap batas auto-rejection [9]. Kebijakan 30 menit trading halt yang diberlakukan saat IHSG mengalami penurunan lebih dari 5\% dan penurunan lanjutan lebih dari 10\% diharapkan mampu mengatasi penurunan yang sangat tajam terhadap IHSG. Selain itu, apabila IHSG kembali menurun hingga lebih dari $15 \%$ maka diberlakukan trading suspend. Sedangkan perubahan batasan auto rejection diharapkan mampu mengurangi tekanan terhadap pasar saham Indonesia. Di sisi lain, Bank Indonesia cenderung menetapkan penurunan BI 7-Days Reverse Repo Rate (BI7DRR) untuk mendukung upaya pemulihan ekonomi nasional [1]. Hal ini sejalan dengan keyakinan bahwa kebijakan moneter mampu menstabilkan harga [14].

Pergerakan nilai IHSG yang sangat fluktuatif selama pandemi Covid-19 tersebut menyebabkan analisis pengaruh BI 7-Days Repo Rate terhadap IHSG perlu dilakukan. Hal tersebut sangat berguna agar pemerintah dapat menetapkan kebijakan yang tepat dalam mengendalikan nilai IHSG, khususnya dengan mengatur BI 7-Days Repo Rate. Robiyanto [19] dalam penelitiannya menunjukkan bahwa koefisien regresi BI rate pada persamaan model regresi IHSG adalah $-15,290$ dengan nilai statistik $t$ sebesar -2,807 sehingga signifikan pada taraf signifikansi $1 \%$. Berdasarkan hal tersebut, didapatkan hasil bahwa peningkatan BI rate cenderung berdampak negatif terhadap IHSG. Sebaliknya, beberapa penelitian lain menyatakan hal sebaliknya yaitu peningkatan BI rate akan memberikan efek positif terhadap return saham [21].

Salah satu metode yang sering digunakan dalam analisis pengaruh adalah regresi parametrik. Melalui analisis regresi parametrik, hubungan fungsional antar variabel dapat diketahui. Dalam hal ini, akan digunakan pendekatan meminimumkan kuadrat error. Namun, pendekatan ini 


\section{Jurnal Matematika, Statistika \& Komputasi Christopher Andreas, Feevrinna Yohannes H, Elfhira Juli S, Nur Chamidah}

memiliki banyak asumsi yang harus dipenuhi sehingga pada banyak kasus, kurang sesuai untuk digunakan.

Untuk mengatasi masalah tersebut, digunakan sebuah pendekatan baru dalam melihat hubungan antara BI 7-Days Repo Rate dengan IHSG yaitu melalui pendekatan regresi nonparametrik. Melalui pendekatan regresi nonparameterik, fungsi regresi dapat ditentukan berdasarkan estimator regresi nonparametrik sehingga memiliki tingkat fleksibilitas yang tinggi [20]. Estimator Least Square Spline (LS-Spline) dipilih karena mampu mengikuti pola perilaku data yang berfluktuasi dengan menempatkan titik knot. Pemilihan model terbaik dilakukan dengan membandingkan nilai Generalized Cross Validation (GCV), dimana nilai GCV terendah menunjukkan model yang optimal [11-12,20]. Pendekatan ini telah banyak dipelajari dan diterapkan oleh berbagai peneliti [13]. Salah satunya adalah pemodelan tekanan darah yang berbasis pada nilai stress. Pendekatan regresi nonparameterik dengan estimator LS-Spline terbukti mampu menghasilkan model yang optimal $[4,6]$.

Pendekatan regresi parametrik dan regresi nonparametrik dirancang untuk menganalisis hubungan yang bersifat fungsional yang terbentuk antara variabel respon dan variabel prediktor. Perbandingan terhadap kedua pendekatan tersebut sangat penting untuk dilakukan guna mendapatkan pendekatan yang lebih baik dalam pemodelan BI 7-Days Repo Rate terhadap IHSG sehingga interpretasi yang diperoleh lebih akurat. Dengan membandingkan ukuran kebaikan dan akurasi model seperti Mean Square Error (MSE), koefisien determinasi, Mean Absolute Percentage Error (MAPE), dan Mean Absolute Deviation (MAD) maka model terbaik dapat ditentukan [15]. Dalam banyak kasus, metode regresi nonparametrik menunjukkan hasil yang lebih baik daripada metode regresi parameterik seperti pada kasus estimasi nilai mean arterial pressure yang dipengaruhi tingkat stress [5]. Sedangkan pada kasus data IHSG, hal tersebut membutuhkan penerapan dan pengujian lebih lanjut.

Dengan membandingkan model regresi yang diperoleh dari dua pendekatan tersebut, maka model terbaik dengan tingkat akurasi yang tinggi dapat diperoleh sehingga interpretasi terhadap pengaruhnya dapat dianalisis dengan baik. Selain itu, dilakukan prediksi menggunakan data outsample untuk menguji kemampuan akurasi dari model yang diperoleh. Hasil penelitian ini sangat bermanfaat bagi pengembangan model statistika yang optimal sehingga dapat dijadikan acuan dalam menetapkan kebijakan terkait BI 7-Days Repo Rate dalam pengaruhnya terhadap IHSG.

\section{TINJAUAN PUSTAKA}

\section{A. BI 7-Days Repo Rate}

Bank Indonesia telah menetapkan bahwa suku bunga yang merefleksikan sikap kebijakan moneter adalah BI Rate. Namun, istilah BI Rate sudah ditinggalkan sejak Agustus 2016 dan diganti dengan BI 7-Days Repo Rate. Istilah tersebut diterapkan untuk menggambarkan suku bunga kebijakan baru. Hal tersebut diterapkan karena efeknya yang lebih cepat terjadi dalam pasar modal, perbankan, dan sektor riil [2]. Instrumen tersebut diyakini memiliki kaitan yang lebih erat dengan suku bunga pasar modal dan mampu mendorong pasar keuangan yang lebih bersifat transaksional.

\section{B. Indeks Harga Saham Gabungan (IHSG)}

Bursa Efek Indonesia (BEI) menggunakan berbagai indeks pasar modal di Indonesia. Salah satu diantaranya adalah Indeks Harga Saham Gabungan (IHSG). Selain itu, IHSG juga digunakan sebagai alat ukur terkait kenaikan atau penurunan harga saham [10]. Jika harga suatu saham mengalami kenaikan dan IHSG juga mengalami kenaikan maka dapat disimpulkan bahwa saham 


\section{Jurnal Matematika, Statistika \& Komputasi Christopher Andreas, Feevrinna Yohannes H, Elfhira Juli S, Nur Chamidah}

tersebut dan IHSG memiliki hubungan positif. Namun, hubungan atau korelasi negatif juga dapat terbentuk apabila harga saham dan IHSG memiliki kecenderungan trend yang berlawanan.

\section{Regresi Parametrik}

Analisis regresi parametrik memiliki beberapa asumsi yang sangat kuat, seperti bentuk kurva regresi yang telah diketahui. Kegunaan pendekatan ini adalah untuk menganalisis hubungan yang terbentuk antar variabel yaitu satu atau beberapa variabel prediktor dengan variabel respon. Kurva regresi membentuk hubungan tertentu, seperti bentuk linier, kuadratik, kubik dan sebagainya. Dalam regresi parametrik, untuk variabel respon disebut juga variabel dependent (variabel terikat) yang dinotasikan dengan variabel $Y$ dan variabel prediktor yang disebut variabel independent (variabel bebas) dan dinotasikan dengan $X$.

Secara umum bentuk model regresi linier berganda dalam hal ini linier dalam parameter dengan prediktor $k$ dapat dituliskan sebagai berikut [15,17-18].

$$
Y_{i}=\beta_{0}+\beta_{1} X_{1}+\cdots+\beta_{k} X_{k}+\varepsilon_{i}
$$

Dalam bentuk notasi matriks, model regresi linier berganda untuk $p$ parameter dan $n$ observasi ditulis sebagai berikut.

$$
\boldsymbol{Y}=\boldsymbol{X} \boldsymbol{\beta}+\boldsymbol{\varepsilon}
$$

Dengan $\boldsymbol{Y}$ dikatakan sebagai variabel respon berupa vektor kolom ukuran $n \times 1$, sedangkan $\boldsymbol{X}$ merupakan matriks ukuran $n \times p$. Parameter $\boldsymbol{\beta}$ sebagai vektor yang berisi jumlah parameter sehingga ukurannya $p \times 1$, dan $\varepsilon$ adalah vektor dari variabel acak yang berdistribusi normal secara independen.

Untuk mengestimasi parameter dari model regresi linier, salah satu metode yang biasa digunakan adalah metode Ordinary Least Square (OLS). Meminimalkan kuadrat residual adalah prinsip dasar dari penggunaan metode ini. Estimator kuadrat terkecil dapat diperoleh melalui bentuk sebagai berikut.

$$
\widehat{\boldsymbol{\beta}}=\left(\boldsymbol{X}^{T} \boldsymbol{X}\right)^{-1} \boldsymbol{X}^{T} \boldsymbol{Y}
$$

\section{Regresi Nonparametrik}

Regresi nonparametrik adalah model statistik untuk mendeteksi hubungan antara variabel respon dengan variabel prediktor. Pada model ini, bentuk dari fungsi regresi tidak diketahui dan kurva regresi tidak diketahui atau kurva regresi nonparametrik tidak membentuk pola tertentu. Berikut merupakan bentuk umum dari regresi nonparametrik [20].

$$
Y_{i}=m\left(x_{i}\right)+\varepsilon_{i}
$$

Dengan $Y_{i}$ adalah variabel respon pengamatan ke- $i, x_{i}$ adalah variabel prediktor pengamatan komponen nonparametrik ke- $i, m$ adalah fungsi regresi yang tidak diketahui dan $\varepsilon_{i}$ adalah residual ke- $i$ dengan asumsi residual regresi bersifat acak dengan rata-rata 0 dan varians $\sigma^{2}$. Dalam regresi nonparametrik, asumsi yang mendasari regresi parametrik dapat diabaikan. Untuk mengestimasi fungsi regresi, fungsi regresi nonparametrik yaitu fungsi $m$ diasumsikan berbentuk mulus. Dalam regresi nonparametrik, dapat dilakukan estimasi dengan beberapa estimator, salah satunya adalah estimator Least Square Spline (LS-Spline).

Pada estimator $L S$-Spline, terdapat potongan polinomial pada segmen berbeda yang disatukan pada knot tertentu. Fungsi regresi pada orde $p$ dan titik knot $\tau_{1}, \tau_{2}, \ldots, \tau_{k}$ dapat ditulis sebagai berikut $[4,6-7,20]$. 


\section{Jurnal Matematika, Statistika \& Komputasi}

\section{Christopher Andreas, Feevrinna Yohannes H, Elfhira Juli S, Nur Chamidah}

$$
f(x)=\sum_{j=0}^{p+k} \beta_{j} \varphi_{j}(x)
$$

Dengan,

$$
\varphi_{j}(x)=\left\{\begin{aligned}
x^{j} & \text { untuk } 0 \leq j \leq p \\
\left(x-\tau_{j-p}\right)_{+}^{p} & \text { untuk } p+1 \leq j \leq p+k
\end{aligned}\right.
$$

Penggunaan estimator LS-Spline didasarkan pada pemilihan jumlah knot dan letak titik knot. Hal ini dapat ditentukan melalui trend yang terbentuk dari plot data. Dalam hal ini, penempatan titik knot akan bertambah seiring dengan pola data yang semakin fluktuatif sehingga membutuhkan banyak keleluasaan dalam mengikuti pola datanya.

\section{E. Ukuran Kebaikan Model Regresi}

Suatu pemodelan dapat dikatakan baik apabila model tersebut mampu merepresentasikan data aktual dengan tingkat akurasi yang tinggi. Kesalahan yang terjadi dalam memprediksi suatu nilai atau berdasarkan pemodelan yang diperoleh merupakan unsur kesalahan akibat ketidakpastian atau error. Besarnya penyimpangan yang terjadi dapat disebabkan oleh besarnya faktor yang tidak dapat diduga (outlier) maupun kesalahan dalam memilih pemodelan yang sesuai. Dalam hal ini, nilai error dapat disebabkan oleh ketidakmampuan model dalam memprediksi komponen trend, musiman, ataupun siklus yang terjadi dalam sebuah data. Jika $y_{i}$ adalah nilai data aktual observasi ke- $i$ dan $\widehat{y}_{l}$ merupakan nilai taksiran dari observasi ke- $i$, maka nilai kesalahan observasi ke- $i$ dapat dituliskan sebagai berikut $[15,18]$.

$$
e_{i}=y_{i}-\widehat{y}_{l}
$$

Melalui nilai kesalahan ini, maka dapat didefinisikan ukuran kebaikan dan ketepatan model sebagai berikut [15-16].

Mean Square Error (MSE)

$$
M S E=\frac{1}{n} \sum_{i=1}^{n} e_{i}^{2}
$$

Koefisien Determinasi

$$
R^{2}=1-\frac{\sum_{i=1}^{n} e_{i}}{\sum_{i=1}^{n}\left(y_{i}-\bar{y}\right)^{2}}
$$

Mean Absolute Percentage Error (MAPE)

$$
M A P E=\frac{1}{n} \sum_{i=1}^{n} \frac{\left|e_{i}\right|}{y_{i}}
$$

Mean Absolute Deviation (MAD)

$$
M A D=\sum_{i=1}^{n} \frac{\left|e_{i}\right|}{n}
$$

Dalam hal ini MAPE akan digunakan sebagai indikator utama dalam menguji keakuratan model. Kategori tingkat akurasi model berdasarkan nilai MAPE disajikan pada Tabel 1. 


\section{Jurnal Matematika, Statistika \& Komputasi Christopher Andreas, Feevrinna Yohannes H, Elfhira Juli S, Nur Chamidah}

Tabel 2.1. Kategori Tingkat Akurasi.

\begin{tabular}{cc}
\hline MAPE (\%) & Interpretasi \\
\hline$<10$ & High accurate prediction \\
\hline $10-20$ & Good prediction \\
\hline $20-50$ & Reasonable \\
\hline$>50$ & Inaccurate \\
\hline
\end{tabular}

\section{METODE PENELITIAN}

\section{A. Sumber Data dan Variabel Penelitian}

Penelitian ini berbasis pada pendekatan deskriptif kuantitatif serta termasuk penelitian asosiatif. Tujuan penelitian ini adalah untuk menganalisis pengaruh atau keterkaitan sebab akibat antara variabel prediktor $(X)$ dan variabel respon $(Y)$, serta dilakukan atas peristiwa yang terjadi dan untuk mengungkap fakta. Variabel penelitian yang digunakan adalah BI 7-Days Repo Rate sebagai variabel prediktor dan Indeks Harga Saham Gabungan (IHSG) sebagai variabel respon.

Sumber data IHSG diperoleh dari Yahoo Finance, sedangkan data BI 7-Days Repo Rate bersumber dari website resmi Bank Indonesia. Penelitian ini menggunakan data sekunder yaitu data penelitian tidak diperoleh dari hasil pengumpulan sampel ataupun observasi melainkan didapat dari sumber data terpercaya yang telah tersedia. Data tersebut merupakan data nilai rataan dari IHSG setiap minggu serta nilai BI 7-Days Repo Rate setiap minggunya. Data penelitian yang digunakan sebanyak 46 data yaitu sejak minggu ke-1 Januari 2020 hingga minggu ke-3 November 2020. Selanjutnya data penelitian terbagi dalam dua bagian yaitu data in-sample dan data out-sample. Data out-sample terdapat 4 yaitu data pada tanggal 16 Maret, 1 Juni, 17 Agustus, dan 2 November 2020, sedangkan data yang tidak termasuk dalam data out-sample adalah kelompok data in-sample yang berjumlah 42 data. Data in-sample dipakai untuk estimasi parameter model. Di sisi lain, data out-sample dipakai untuk membuat prediksi berdasarkan pemodelan yang telah dilakukan.

\section{B. Prosedur Analisis}

Dalam hal ini, analisis data dilakukan dengan dua pendekatan yaitu pendekatan regresi parametrik dan pendekatan regresi nonparametrik dengan estimator Least Square Spline. Prosedur analisis yang dilakukan adalah sebagai berikut: (1) mengidentifikasi pola data melalui diagram sebar, (2) menguji asumsi umum, (3) pemodelan berdasarkan pendekatan regresi parametrik, (4) pemodelan berdasarkan pendekatan regresi nonparametrik dengan estimator Least Square Spline, (5) membandingkan pengukuran kebaikan model dari setiap hasil pemodelan yang dilakukan, (6) interpretasi berdasarkan model terbaik yang diperoleh dari kedua pendekatan tersebut, dan (7) melakukan peramalan berdasarkan model terbaik.

Pada tahapan ketiga yaitu pemodelan regresi parametrik dilakukan estimasi parameter model regresi linier dan regresi kuadratik sedangkan pada tahapan keempat yaitu regresi nonparametrik dengan estimator Least Square Spline yang dilakukan dalam beberapa tahap yaitu: (1) menentukan orde polinomial yang sesuai, jumlah knot dan lokasi titik knot berdasarkan trend dalam plot data, (2) melakukan estimasi regresi nonparametrik dengan estimator Least Square Spline, (3) memilih model terbaik berdasarkan ukuran kebaikan model dan nilai GCV minimum. 


\section{Jurnal Matematika, Statistika \& Komputasi}

\section{Christopher Andreas, Feevrinna Yohannes H, Elfhira Juli S, Nur Chamidah}

\section{HASIL DAN PEMBAHASAN}

Sebelum melakukan analisis lebih lanjut, disajikan plot data yang terbentuk antar variabel penelitian. Plot data tersebut disajikan pada Gambar 4.1.

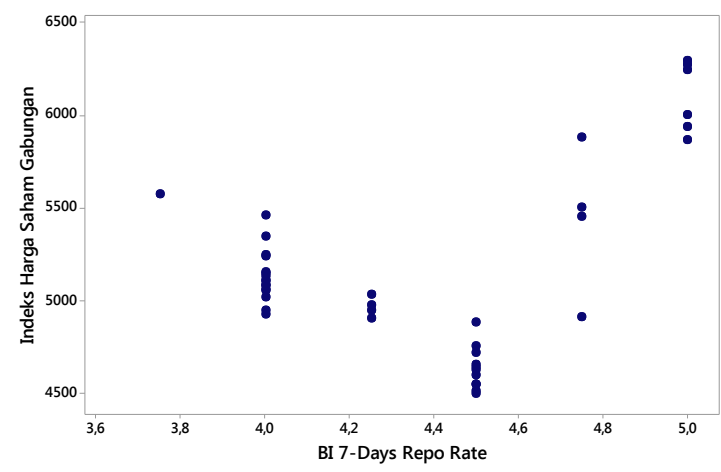

Gambar 4.1. Plot Data BI 7-Days Repo Rate dengan IHSG.

Berdasarkan Gambar 4.1, terlihat bahwa nilai IHSG memiliki kecenderungan monoton turun pada nilai BI 7-Days Repo Rate sebesar 3,5\% hingga 4,5\% dan monoton naik pada nilai BI 7-Days Repo Rate sebesar 4,5\% hingga 5\%. Untuk itu, pemodelan akan dilakukan melalui pendekatan regresi parametrik dan regresi nonparametrik. Dalam hal ini, regresi parametrik akan didekati dengan pola linier dan kuadrat. Sedangkan pada regresi nonparametrik akan digunakan penduga Least Square Spline dengan menempatkan 1 knot point pada setiap nilai BI 7-Days Repo Rate. Hal ini sesuai dengan pola data yang menunjukkan perubahan trend sebanyak 1 kali.

\section{A. Regresi Parametrik}

Pada bagian ini, data BI 7-Days Repo Rate diregresikan dengan data IHSG berdasarkan metode Ordinary Least Square (OLS). Hasil estimasi disajikan pada Tabel 4.1. Pengujian parameter model regresi linier akan menggunakan $\alpha=5 \%$, dalam hal ini jika nilai $p$-value $<\alpha$ maka semua parameter penyusun model regresi linier telah signifikan. Hal yang sama berlaku untuk model regresi kuadrat. Hal tersebut menunjukkan bahwa model regresi linier dan kuadratik layak untuk digunakan. Berdasarkan hasil estimasi pada Tabel 4.1, persamaan model yang diperoleh dapat dituliskan sebagai berikut.

Regresi Linear

Regresi Kuadratik

$$
\widehat{Y}=2716+561 X
$$

$$
\widehat{Y}=67336-28806 X+3312 X^{2}
$$

Tabel 4.1. Hasil Estimasi Regresi Parametrik.

\begin{tabular}{cccccc}
\hline Model Regresi & Parameter & Koefisien & Std. Error & Statistik $t$ & $P$-value \\
\hline \multirow{2}{*}{ Linear } & $\beta_{0}$ & 2716 & 831 & 3,27 & 0,002 \\
\cline { 2 - 6 } & $\beta_{1}$ & 561 & 190 & 2,96 & 0,005 \\
\hline \multirow{3}{*}{ Kuadratik } & $\beta_{0}$ & 67336 & 5462 & 12,33 & 0,000 \\
\cline { 2 - 6 } & $\beta_{1}$ & -28806 & 2477 & $-11,63$ & 0,000 \\
\cline { 2 - 6 } & $\beta_{2}$ & 3312 & 279 & 11,86 & 0,000 \\
\hline
\end{tabular}




\section{Jurnal Matematika, Statistika \& Komputasi Christopher Andreas, Feevrinna Yohannes H, Elfhira Juli S, Nur Chamidah}

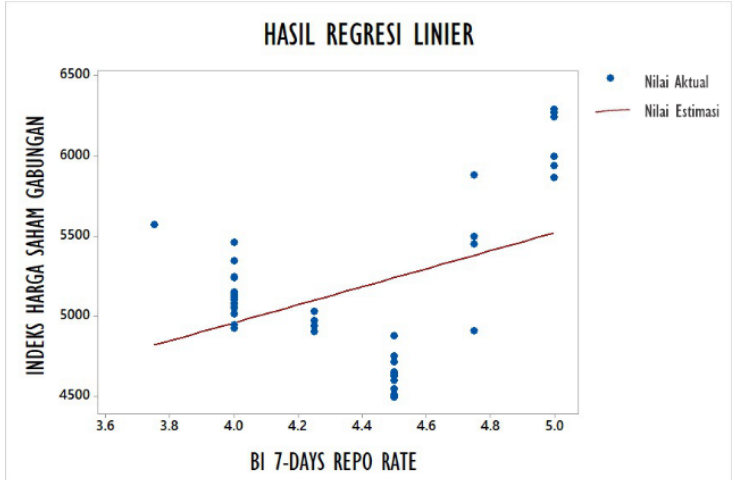

(a)

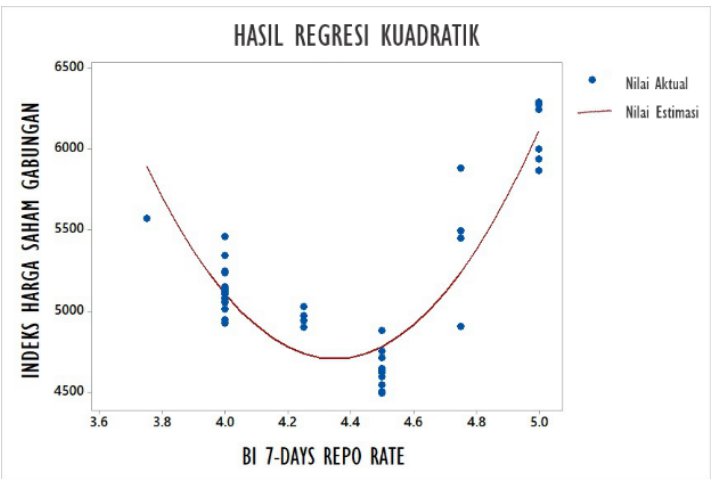

(b)

Gambar 4.2. Plot Hasil Pemodelan (a) Regresi Linear dan (b) Regresi Kuadratik

Hasil pemodelan regresi parametrik disajikan pada Gambar 4.2. Berdasarkan plot data aktual pada Gambar 4.2 terlihat bahwa data tidak membentuk trend linier sehingga pemodelan dengan regresi linier kurang memuaskan. Hal tersebut dibuktikan dengan nilai koefisien determinasi yang relatif rendah yaitu sebesar $17,19 \%$. Dengan kata lain, BI 7-Days Repo Rate hanya mampu menjelaskan 17,19\% data IHSG jika model regresi linier digunakan. Selain itu, nilai kebaikan dan akurasi model lain seperti MSE, MAPE, MAD menunjukkan nilai yang besar, seperti yang disajikan pada Tabel 4.2. Guna memperbaiki model regresi linier, dilakukan peningkatan orde menjadi regresi kuadratik, dan diperoleh nilai koefisien determinasi meningkat drastis menjadi 82,19\%. Nilai MSE, MAPE, dan MAD juga menunjukkan hasil yang lebih baik jika dibandingkan dengan model regresi linier.

Tabel 4.2. Ukuran Kebaikan dan Akurasi Model Regresi Parametrik.

\begin{tabular}{lllll}
\hline Model Regresi & MSE & Koefisien Determinasi & MAPE & MAD \\
\hline Linear & 207965 & $17,92 \%$ & $7,20 \%$ & 368,83 \\
\hline Kuadratik & 46291 & $82,19 \%$ & $3,26 \%$ & 168,60 \\
\hline
\end{tabular}

Dalam pendekatan regresi parametrik, beberapa asumsi klasik harus dipenuhi. Pengujian asumsi klasik dalam penelitian ini meliputi asumsi bahwa residual model regresi berdistribusi normal baku, varians kesalahan tidak dipengaruhi oleh variabel prediktor, dan tidak ada korelasi dengan galat yang disusun menurut urutan waktu. Untuk menguji asumsi klasik tersebut, dilakukan uji Kolmogorov-Smirnov, uji Park, dan uji Breusch-Godfrey.

Secara ringkas, hasil uji asumsi disajikan pada Tabel 4.3. Meskipun model regresi kuadrat telah menunjukkan hasil yang signifikan untuk masing-masing parameternya dan memiliki ukuran kebaikan model yang cukup baik, namun terdapat asumsi heteroskedastisitas yang belum berhasil terpenuhi. Oleh karena itu, pendekatan regresi parametrik menggunakan metode estimasi OLS tidak cocok digunakan sebab pada data yang bersifat heteroskedastik, penggunaan regresi parametrik tetap dapat digunakan dengan terlebih dahulu melakukan proses transformasi terhadap model regresi. Metode estimasi parameter melalui model regresi hasil transformasi ini dikenal sebagai Generalized Least Square (GLS). Untuk itu diperlukan pendekatan lain yaitu pendekatan regresi nonparametrik yang bebas dari asumsi klasik serta memiliki derajat fleksibilitas yang tinggi. 


\section{Jurnal Matematika, Statistika \& Komputasi}

\section{Christopher Andreas, Feevrinna Yohannes H, Elfhira Juli S, Nur Chamidah}

Tabel 4.3. Hasil Pengujian Asumsi Klasik.

\begin{tabular}{|c|c|c|}
\hline \multirow{2}{*}{ Jenis Pengujian } & \multicolumn{2}{|c|}{ Model Regresi } \\
\hline & Linear & Kuadratik \\
\hline $\begin{array}{l}\text { Pengujian Normalitas } \\
\text { Residual Menggunakan Uji } \\
\text { Kolmogorov-Smirnov } \\
(\alpha=5 \%)\end{array}$ & $\begin{array}{l}\text { Residual model membentuk } \\
\text { distribusi normal dengan p- } \\
\text { value sebesar } 0,112 \text {. }\end{array}$ & $\begin{array}{l}\text { Residual model membentuk } \\
\text { distribusi normal dengan p- } \\
\text { value lebih dari } 0,150 \text {. }\end{array}$ \\
\hline $\begin{array}{l}\text { Pengujian Heterokedastisitas } \\
\text { Menggunakan Uji Park } \\
(\alpha=5 \%)\end{array}$ & $\begin{array}{l}\text { Terdapat kasus } \\
\text { heterokedastisitas. }\end{array}$ & $\begin{array}{l}\text { Terdapat kasus } \\
\text { heterokedastisitas. }\end{array}$ \\
\hline $\begin{array}{l}\text { Pengujian Autokorelasi } \\
\text { Menggunakan Uji Breusch- } \\
\text { Godfrey }(\alpha=5 \%)\end{array}$ & Terdapat kasus autokorelasi. & $\begin{array}{l}\text { Tidak terdapat kasus } \\
\text { autokorelasi. }\end{array}$ \\
\hline
\end{tabular}

\section{B. Regresi Non Parametrik}

Berdasarkan plot data pada Gambar 4.1, terlihat bahwa data memiliki kecenderungan berbelok arah pada 1 titik. Oleh karena itu, estimasi regresi nonparametrik dengan estimator $L S$-Spline ini menggunakan 1 titik knot. Titik knot tersebut diletakkan pada setiap titik nilai variabel prediktor. Selain itu, orde polinomial yang digunakan adalah orde 1 dan orde 2 . Untuk memilih model yang optimal, digunakan kriteria ukuran GCV, dimana model dengan nilai GCV yang paling minimum adalah model terbaik. Nilai GCV pada setiap kemungkinan model ditampilkan pada Gambar 4.3.

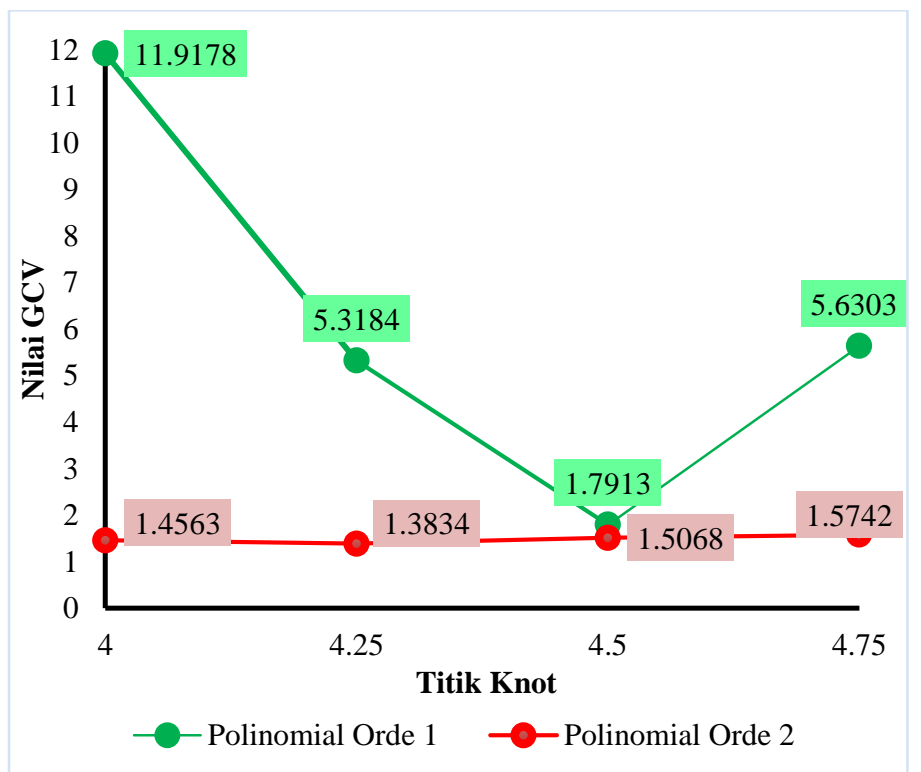

Gambar 4.3. Nilai GCV pada Setiap Titik Knot dengan Orde Polinomial 1 dan Orde Polinomial 2.

Berdasarkan Gambar 4.3, terlihat bahwa nilai GCV minimum yang diperoleh dari estimasi model dengan orde polinomial 1 terjadi pada titik knot sebesar 4,5 dengan nilai sebesar 1,7913. Disisi lain, estimasi model pada orde polinomial 2 menghasilkan nilai GCV minimum sebesar 1,3834 yaitu di titik knot sebesar 4,25. Terlihat bahwa nilai GCV minimum pada orde polinomial 2 lebih kecil daripada GCV minimum pada orde polinomial 1. Perbandingan nilai GCV tersebut 


\section{Jurnal Matematika, Statistika \& Komputasi}

\section{Christopher Andreas, Feevrinna Yohannes H, Elfhira Juli S, Nur Chamidah}

disajikan pada Tabel 4.4. Dengan demikian, dilakukan estimasi model pada orde polinomial 2 dan titik knot 4,25. Hasil estimasi regresi nonparametrik tersebut disajikan pada Tabel 4.5.

Tabel 4.4. Nilai GCV.

\begin{tabular}{ccc}
\hline Orde Polinomial & Titik Knot & Nilai GCV \\
\hline \multirow{3}{*}{1} & 4 & 11,9178 \\
\cline { 2 - 3 } & 4,25 & 5,3184 \\
\cline { 2 - 3 } & 4,5 & 1,7913 \\
\cline { 2 - 3 } & 4,75 & 5,6303 \\
\hline \multirow{2}{*}{2} & 4 & 1,4563 \\
\cline { 2 - 3 } & 4,25 & 1,3834 \\
\cline { 2 - 3 } & 4,5 & 1,5068 \\
\hline
\end{tabular}

Tabel 4.5. Hasil Estimasi Regresi Nonparametrik.

\begin{tabular}{cc}
\hline Parameter & Koefisien \\
\hline$\beta_{0}$ & 14919,28 \\
\hline$\beta_{1}$ & $-3459,26$ \\
\hline$\beta_{2}$ & 253,90 \\
\hline$\beta_{3}$ & 3883,59 \\
\hline
\end{tabular}

Berdasarkan hasil estimasi pada Tabel 4.5, model regresi nonparametrik tersebut dapat dituliskan sebagai berikut.

$$
\widehat{y}_{\iota}=14919,28-3459,26 x_{i}+253,90 x_{i}^{2}+3883,59\left(x_{i}-4,25\right)_{+}^{2}
$$

Persamaan model tersebut dapat dinyatakan menjadi bentuk lain yaitu sebagai berikut.

$$
\widehat{y}_{l}=\left\{\begin{array}{lr}
14919,28-3459,26 x_{i}+253,90 x_{i}^{2} & \text { if } x_{i} \leq 4,25 \% \\
85066,69-36469,81 x_{i}+4137,49 x_{i}^{2} & \text { if } x_{i}>4,25 \%
\end{array}\right.
$$

Secara umum, persamaan regresi nonparametrik pada Persamaan 4.3 atau yang dituliskan secara lengkap pada Persamaan 4.4 telah memiliki ukuran kebaikan dan akurasi model yang baik. Hal ini dapat terlihat dari nilai MSE, MAPE, dan MAD yang relatif kecil. Selain itu, nilai koefisien determinasi relatif tinggi. Nilai tersebut disajikan pada Tabel 4.6. Model tersebut memiliki nilai koefisien determinasi sebesar $84,39 \%$. Dengan kata lain, model ini mampu mendeskripsikan keragaman data hingga 84,39\%. Lebih lanjut, nilai MAPE sebesar 2,92\% mengindikasikan akurasi yang tinggi (high accurate prediction) seperti yang disajikan pada Gambar 4.4. Selain itu, berdasarkan Gambar 4.4, terlihat bahwa secara visual, hasil estimasi mampu memberikan nilai prediksi yang baik terhadap data aktual. Dengan demikian, model ini memiliki akurasi yang baik. 


\section{Jurnal Matematika, Statistika \& Komputasi}

\section{Christopher Andreas, Feevrinna Yohannes H, Elfhira Juli S, Nur Chamidah}

Tabel 4.6. Ukuran Kebaikan dan Akurasi dari Model Regresi Nonparametrik.

\begin{tabular}{llll}
\hline MSE & Koefisien Determinasi & MAPE & MAD \\
\hline 37663,09 & $84,39 \%$ & $2,92 \%$ & 151,96 \\
\hline
\end{tabular}

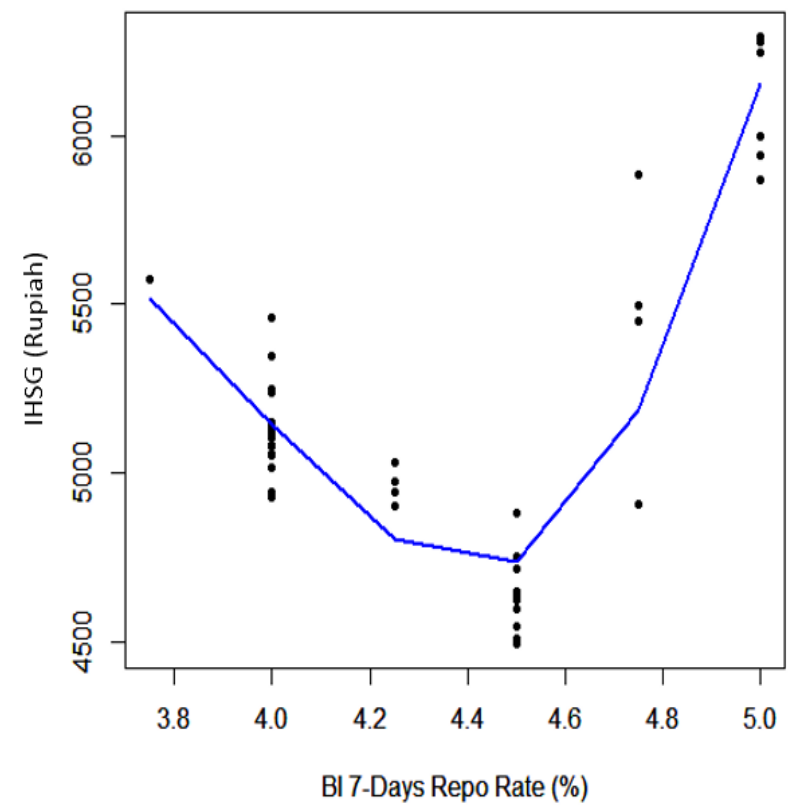

Gambar 4.4. Plot Hasil Pemodelan Regresi Nonparametrik.

Dari grafik pada Gambar 4.4 dapat terlihat bahwa dengan menggunakan regresi nonparametrik pengaruh BI 7-Days Repo Rate terhadap IHSG digambarkan dengan lebih sesuai. Lebih lanjut, akan dilakukan pengujian asumsi pada model regresi nonparametrik yang telah diperoleh. Dalam hal ini, mean dari residual harus bernilai nol dan memiliki varians $\sigma^{2}$. Lebih lanjut, residual model tersebut juga harus tidak saling berkorelasi serial. Untuk itu, dilakukan pengujian hipotesis rata - rata melalui uji $t$ pada 1 sampel independen terhadap residual model. Hasil pengujian disajikan pada Tabel 4.7. Dengan hipotesis nol yaitu mean residual bernilai nol dan hipotesis alternatif yaitu mean residual tidak sama dengan nol, diperoleh nilai $p$-value sebesar 0,999. Oleh karena itu, dapat disimpulkan bahwa residual model bernilai nol. Secara visual, hal tersebut dalam dilihat melalui histogram dari residual model yang disajikan pada Gambar 4.5. Selain itu, berdasarkan uji Breusch-Godfrey, diperoleh bahwa residual model tidak berkorelasi secara serial. Dengan demikian, model ini tepat untuk digunakan.

Tabel 4.7. Hasil Pengujian Hipotesis untuk Mean Residual.

\begin{tabular}{cccc}
\hline Mean & Simpangan Baku & Statistik $t$ & $P$-Value \\
\hline 0,029 & 196,417 & 0,000 & 0,999 \\
\hline
\end{tabular}




\section{Jurnal Matematika, Statistika \& Komputasi}

\section{Christopher Andreas, Feevrinna Yohannes H, Elfhira Juli S, Nur Chamidah}

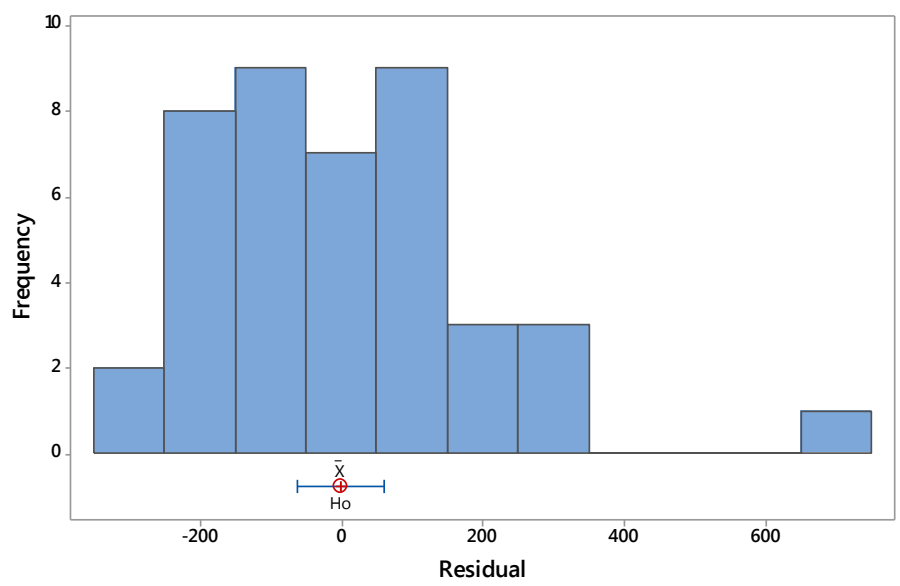

Gambar 4.5. Histogram dari Residual pada Model Regresi Nonparametrik.

\section{Peramalan dan Interpretasi Model}

Peramalan dilakukan menggunakan model regresi terbaik. Dalam hal ini, model terbaik tersebut diperoleh dari pendekatan regresi nonparametrik. Perbandingan hasil pemodelan yang diperoleh dari dua pendekatan yang telah dilakukan pada bagian sebelumnya disajikan pada Gambar 4.6.

Nilai Aktual $\quad-$ Regresi Parametrik $\quad \longrightarrow$ Regresi Nonparametrik

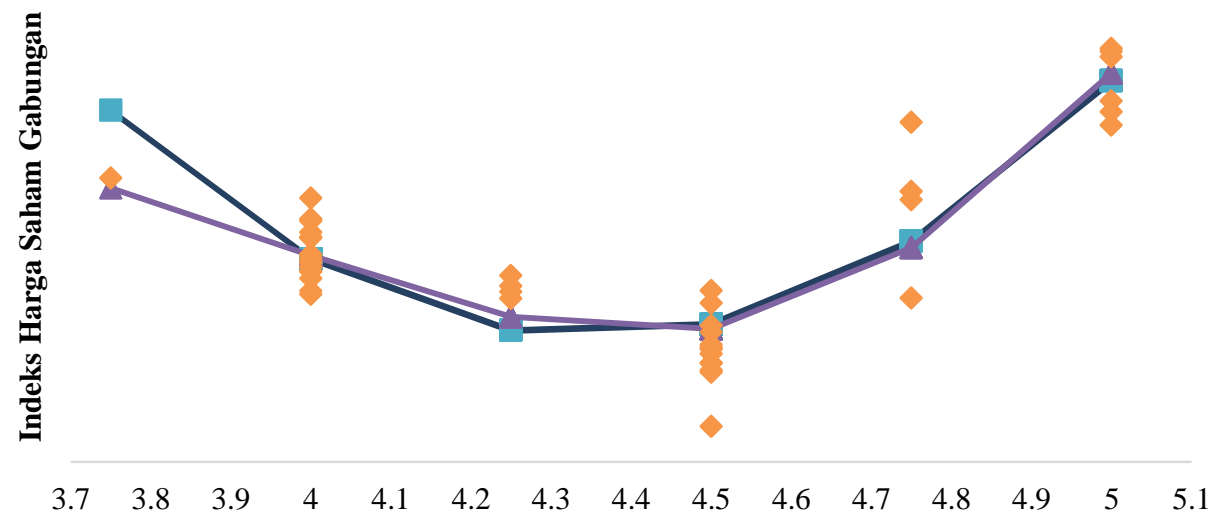

BI 7-Days Repo Rate

Gambar 4.6. Perbandingan Plot Hasil Pemodelan Berdasarkan Pendekatan Regresi Parametrik dan Regresi Nonparametrik.

Pada bagian ini, peramalan dilakukan dengan menggunakan data out-sample. Hal ini dilakukan untuk menguji keakuratan model yang diperoleh sebelumnya. Hasil peramalan pada data out-sample disajikan pada Tabel 4.8. Berdasarkan hasil peramalan pada Tabel 4.8, dapat diketahui bahwa nilai MAPE dari data out-sample adalah 5,79\%. Nilai tersebut mengindikasikan bahwa model yang diperoleh memiliki tingkat akurasi yang tinggi dalam memprediksi nilai IHSG berdasarkan BI 7-Days Repo Rate dengan nilai MAPE keseluruhan sebesar 3,16\%. Secara umum, pengaruh variabel prediktor terhadap variabel respon membentuk pola kuadratik. Jika BI 7-Days 


\section{Jurnal Matematika, Statistika \& Komputasi Christopher Andreas, Feevrinna Yohannes H, Elfhira Juli S, Nur Chamidah}

Repo Rate ditetapkan di bawah atau sama dengan 4,25\%, maka nilai IHSG akan mengalami penurunan. Di sisi lain, jika BI 7-Days Repo Rate ditetapkan di atas 4,25\%, maka nilai IHSG akan meningkat. Setiap kenaikan $0,25 \%$ pada variabel prediktor apabila variabel prediktor ditetapkan pada tingkatan $\leq 4,25 \%$ maka nilai variabel respon akan turun rata-rata sebesar 1428,04. Sementara itu, kenaikan variabel prediktor sebesar $0,25 \%$ apabila variabel prediktor berada pada level $>4,25 \%$ akan menyebabkan nilai variabel respon naik secara rata-rata sebesar 4904,68 .

Tabel 4.8. Hasil Peramalan

\begin{tabular}{cccccc}
\hline No. & $\begin{array}{c}\text { BI 7-Days Repo } \\
\text { Rate }(\%)\end{array}$ & $\begin{array}{c}\text { Nilai Aktual } \\
\text { IHSG }\end{array}$ & Hasil Peramalan & Nilai Galat & APE \\
\hline 1 & 4,5 & 4194,94 & 4736,792 & $-541,852$ & 0,129168 \\
\hline 2 & 4,5 & 4947,78 & 4736,792 & 210,9881 & 0,042643 \\
\hline 3 & 4 & 5272,81 & 5144,622 & 128,1876 & 0,024311 \\
\hline 4 & 4 & 5335,53 & 5144,622 & 190,9076 & 0,03578 \\
\hline & & & MAPE & 0,057976 \\
\hline
\end{tabular}

Secara umum, pola tersebut memang tidak umum terjadi. Menurut teori klasik, peningkatan suku bunga acuan umumnya akan menyebabkan tingkat investasi menurun karena investor akan cenderung menaruh uangnya di bank. Namun, pola klasik tersebut tidak sepenuhnya terjadi selama pandemi Covid-19, khususnya di Indonesia. Kekhawatiran investor terhadap kondisi perekonomian dunia telah menyebabkan perubahan pola perilaku dalam investasi yaitu investor semakin berhati-hati dan melihat situasi perekonomian terbaru sebelum melakukan investasi. Di sisi lain, ada berbagai faktor yang diyakini turut mempengaruhi pergerakan nilai IHSG selain BI 7-Days Repo Rate, seperti nilai kurs mata uang, tingkat inflasi dan kondisi suatu negara. Peningkatan nilai BI 7-Days Repo Rate yang memberi efek pada kenaikan nilai IHSG dapat disebabkan oleh adanya kepercayaan investor terhadap kondisi perekonomian di Indonesia. Hal ini terjadi ketika pandemi Covid-19 belum secara resmi muncul di Indonesia, dimana pada saat tersebut, ada berbagai negara yang telah resmi menemukan kasus pertama pandemi Covid-19.

Di sisi lain, pola klasik yang membentuk hubungan negatif antara BI 7-Days Repo Rate dan IHSG dapat terbentuk ketika pemerintah telah menunjukkan langkah - langkah strategis guna memutus rantai penyebaran Covid-19 serta adanya vaksin Covid-19 sehingga investor melihat adanya proyeksi kondisi ekonomi yang baik di masa mendatang. Hal ini dibuktikan dengan nilai IHSG yang terus meningkat pada bulan Desember 2020 hingga mencapai poin diatas 6000 semenjak diterapkan BI rate sebesar 3,75 yang mengartikan perekonomian terus mengalami pemulihan positif. Namun, dalam penelitian ini, analisis terhadap pergerakan nilai IHSG hanya ditinjau atas pengaruh dari BI 7-Days Repo Rate. Oleh karena itu, diperlukan penelitian selanjutnya untuk menganalisis faktor - faktor lain yang turut dipercaya ikut mempengaruhi pergerakan nilai IHSG sehingga hasil analisis yang diperoleh dapat semakin komprehensif.

\section{KESIMPULAN}

Pada kasus ini, estimator Least Square Spline pada pendekatan regresi nonparametrik sesuai untuk digunakan karena memiliki ukuran kebaikan dan ukuran akurasi model yang baik. Di sisi lain, pendekatan regresi parametrik tidak menghasilkan model yang optimal karena ada beberapa asumsi klasik yang tidak dipenuhi. Berdasarkan hasil analisis, diperoleh bahwa terdapat hubungan negatif antara BI 7-Days Repo Rate dan IHSG ketika BI 7-Days Repo Rate berada di level kurang dari atau sama dengan $4.25 \%$. Sebaliknya, hubungan positif terbentuk ketika BI 7- 


\section{Jurnal Matematika, Statistika \& Komputasi}

Christopher Andreas, Feevrinna Yohannes H, Elfhira Juli S, Nur Chamidah

Days Repo Rate berada di level yang lebih dari 4.25\%. Meskipun demikian, pergerakan nilai IHSG juga dipengaruhi oleh berbagai faktor, selain BI 7-Days Repo Rate, seperti tingkat kurs terhadap rupiah dan tingkat inflasi sehingga penelitian lebih lanjut diperlukan guna mempelajari pergerakan nilai IHSG secara lebih komprehensif.

\section{ACKNOWLEDGEMENT}

Penulis mengucapkan terima kasih kepada Fakultas Sains dan Teknologi, Universitas Airlangga yang mendukung kelancaran kegiatan penelitian ini.

\section{CONFLICT OF INTEREST}

Penelitian ini murni bertujuan untuk memberikan tinjauan statistik terkait hubungan fungsional antara BI 7-Days Repo Rate terhadap IHSG dan tidak ada konflik kepentingan didalamnya.

\section{DAFTAR PUSTAKA}

[1] Bank Indonesia. 2020. BI 7-Day Reverse Repo Rate Lowered 25 bps to $3.75 \mathrm{e} \%$ : Synergy Driving the National Economy Recovery. Press Release No 22/87/Dkom.

[2] Bank Indonesia. 2020. BI 7-Day (Reverse) Repo Rate. https://www.bi.go.id/en/moneter/bi-7day-RR/penjelasan/Contents/Default.aspx. [Diakses Oktober 2020]

[3] Cabinet Secretariat of the Republic of Indonesia. 2020. Implement Health Protocols. https://setkab.go.id/en/covid-19-working-committee-constantly-reminds-people-toimplement-health-protocols/. [Diakses Oktober 2020]

[4] Chamidah, N., Lestari, B., dan Saifudin, T. 2019. Predicting Blood Pressures and Heart Rate Associated with Stress Level Using Spline Estimator: A Theoretically Discussion. International Journal of Academic and Applied Research (IJAAR), Vol. 3, No.10, 5-12.

[5] Chamidah, N., Lestari, B., Massaid, A., dan Saifudin, T. 2020. Estimating Mean Arterial Pressure Affected By Stress Scores Using Spline Nonparametric Regression Model Approach. Commun. Math. Biol. Neurosci, Vol. 2020, No.72, 1-12.

[6] Chamidah, N., Lestari, B., Wulandari, A. Y., dan Muniroh, L. Z-Score Standard Growth Chart Design of Toddler Weight Using Least Square Spline Semiparametric Regression. AIP Conference Proceedings, In-Press.

[7] Gyorfi, L., Kohler, M., Krzyzak, A., dan Walk, H. 2002. A Distribution-Free Theory of Nonparametric Regression. New York : Springer-Verlage.

[8] Indonesia Stock Exchange. 2020. IDX Implements Proviseions Regarding Trading Halt for Trading in the Exchange. Press Release No 022/BEI/SPR/03-2020.

[9] Indonesia Stock Excange. 2020. IDX Policy Explanation Regarding Changes to the Auto Rejection Limit on Stock Trading on the Exchange. Press Release No. 026/BEI/SPR/032020.

[10] Indonesia Stock Index. 2020. Stock Index. https://www.idx.co.id/en-us/products/index/. [Diakses Oktober 2020]

[11] Lestari, B., Fatmawati, Budiantara, I. N., dan Chamidah, N. 2018. Estimation of Regression Function in Multi-Response Nonparametric Regression Model Using Smoothing Spline and Kernel Estimators. Journal of Physics: Conference Series, Vol. 1097012091.

[12] Lestari, B., Fatmawati, Budiantara, I. N., dan Chamidah, N. 2019. Smoothing Parameter Selection Method for Multiresponse Nonparametric Regression Model Using Smoothing 


\section{Jurnal Matematika, Statistika \& Komputasi}

\section{Christopher Andreas, Feevrinna Yohannes H, Elfhira Juli S, Nur Chamidah}

Spline and Kernel Estimators Approaches. Journal of Physics: Conference Series, Vol. 1397012064.

[13] Lestari, B., Chamidah, N., dan Saifudin T. 2019. Estimasi Fungsi Regresi Dalam Model Regresi Nonparametrik Birespon Menggunakan Estimator Smoothing Spline dan Estimator Kernel. Jurnal Matematika, Statistika, dan Komputasi, Vol. 15, No.2, 20-24.

[14] Mathai, K. 2020. Monetary Policy: Stabilizing Prices and Output. International Monetary Fund. https://www.imf.org/external/pubs/ft/fandd/basics/monpol.htm. [Diakses Oktober 2020]

[15] Montgomery, D. C., Jennings, C. L., dan Kulahci, M. 2008. Introduction to Time Series Analysis and Forecasting. New Jersey: John Willey \& Sons Inc.

[16] Moreno, J. J., Pol, A. P., Abad, A. S., dan Blasco, B. C. 2013. Using the R-MAPE Index as a Resistant Measure of Forecast Accuracy. Psicothema Vol. 25, No.4, 500-506.

[17] Olive, D. J. 2017. Linear Regression. Gewerbestrasse : Springer.

[18] Paolella, M. S. 2019. Linear Models and Time-Series Analysis : Regression, ANOVA, $A R M A$, and GARCH. New Jersey: John Willey \& Sons Inc.

[19] Robiyanto. 2018. The Effect of Gold Price Changes, USD/IDR Exchange Rate Changes and Bank Indonesia (BI) Rate on Jakarta Composite Index (JCI)'Return and Jakarta Islamic Indec (JII)'Return. Journal of Management Vol. 20.

[20] Takezawa, K. 2006. Introduction to Nonparametric Regression. New Jersey: John Willey \& Sons Inc.

[21] Wiradharma, M. S. and Sudjarni, L. K. 2016. Pengaruh Tingkat Suku Bunga, Inflasi, Nilai Kurs Rupiah, dan Produk Domestik Bruto terhadap Return Saham. EJournal Manajemen UNUD Vol. 5 (6), 3392-3420. 